\title{
CLINICAL OPINION: BRUGADA SYNDROME AND SICK SYNUS SYNDROME - CASE WHICH WE MEET IN OUR PRACTICE
}

\author{
Tomislav Kostic ${ }^{1}$, Zoran Perisic ${ }^{1,2}$, Boris Djindjic ${ }^{1,2}$, Goran Koracevic ${ }^{1,2}$, Milan Zivkovic ${ }^{1}$, Aleksandar Stojkovic ${ }^{1}$, Dragana Stanojevic ${ }^{1}$, \\ Vladimir Mitov ${ }^{3}$
}

In our work we describe the case of a patient with a Brugada syndrome. It is a rare syndrome which carries a potential risk of sudden cardiac death which occurs usually at an early age. Unfortunately it is most frequently the first clinical manifestation of this genetic disease. Sometimes, as in our patient it could co-exist with other cardiovascular abnormalities which give us an opportunity to establish the right diagnosis and apply adequate preventive measures. It is of paramount importance to explore the possibility of the existence of this syndrome in the patient's family members. The first diagnostic procedure is an ECG which is an inexpensive and readily available diagnostic tool.

Russ J Cardiol 2014, 1 (105), Engl.: 49-51

Key words: Brugada syndrome, implantable-cardioverter defibrillator, ECG, prevention, sudden cardiac death.
${ }^{1}$ Clinic for cardiovascular diseases, Clinical Centre Nis, Nis; ${ }^{2}$ Medical Faculty, University of Nis; ${ }^{3}$ Health Centre Zajecar, Zajecar, Serbia.

Corresponding author. Dragana Stanojevic, Clinic for cardiovascular diseases, Clinical Centre Nis, Nis, Serbia; Bulevar Zorana Djindjića 48, 18000 Nis, Serbia, Tel:: +38 1643068447, Fax: +381184221674 e-mail: draganastanojevic1@gmail.com

bmp - beats per minute, DDDR - dual chambers paces, dual chambers sensed dual response to this, and rate modifiable pacemaker, ICD - implantablecardioverter defibrillator, ECG- electrocardiogram, SCN5A gene - sodium channel, voltage-gated, type $\mathrm{V}$, alpha subunit gene.

Received September 24, 2013.

Revision received October 16, 2013.

Accepted October 23, 2013.

\section{КЛИНИЧЕСКОЕ МНЕНИЕ: СИНДРОМ БРУГАДА И БОЛЬНЫЕ С СИНДРОМОМ SYNUS - СЛУЧАЙ, КОТОРЫЙ МЫ ВСТРЕТИЛИ В НАШЕЙ ПРАКТИКЕ}

\author{
Tomislav Kostic ${ }^{1}$, Zoran Perisic ${ }^{1,2}$, Boris Djindjic ${ }^{1,2}$, Goran Koracevic ${ }^{1,2}$, Milan Zivkovic ${ }^{1}$, Aleksandar Stojkovic ${ }^{1}$, Dragana Stanojevic ${ }^{1}$, \\ Vladimir Mitov
}

Рассматривается случай пациента с синдром Бругада. Это редкий синдром, который несет потенциальный риск внезапной сердечной смерти, обычно в раннем возрасте. К сожалению, часто смерть - первое клиническое проявление данного генетического заболевания. Иногда у в наших пациентов синдром Бругада может сосуществовать с другими сердечно-сосудистыеми нарушениями, которые дают нам возможность установить правильный диагноз и применить соответствующие превентивные меры. Крайне важно изучить возможность наличия этого синдрома у членов семьи пациента. Первая про-

Patient D.A. was admitted to the Cardiology Clinic due to sudden onset of weakness and slow heart rate, accompanied by dizziness. He was sent from a private clinic where 24-hour Holter monitoring was done and sinus pauses were recorded. Patient was under the continuous ECG monitoring in the coronary care unit. Complete laboratory analysis showed no deviation from the normal values. ECG recorded right bundle branch block with ST segment elevation of $2 \mathrm{~mm}$ in leads V1-V3 (Fig. 1). Biomarkers: D-dimer and troponin I was within normal limits. The next day, an echocardiography was done which showed normal structure of the atria and ventricles, without regional motion abnormalities, adequate valvular apparatus and ejection fraction was $65 \%$. The patient was on monitor for $48 \mathrm{~h}$ and after that period it was decided to repeat Holter monitoring $(24 \mathrm{~h})$. The results showed that average cardiac frequency was $45 \mathrm{bpm}$, minimal $30 \mathrm{bpm}$, maximal $90 \mathrm{bpm}$, a few pauses in cardiac rhythm were detected, the largest 4.5 seconds. The patient was in sinus rhythm during whole monitoring period (Fig. 2). It was decided that the best option was to insert adaptive frequency biventricular DDDR pacemaker. The next day, in цедура диагностики - ЭКГ, которая является недорогим и легкодоступным средством диагностики.

Российский кардиологический журнал 2014, 1 (105), Англ.: 49-51

Ключевые слова: синдром Бругада, имплантируемый кардиовертер дефибриллятор, электрокардиограф, профилактика внезапной сердечной смерти.

a local anaesthesia preparation of vein cephalica was made; electrodes were placed at the top of the right ventricle, appendage of the right atrium. The patient received antibiotics 4 days after the procedure and was discharged in good general condition. After 2 weeks the stitches were removed, and patient was advised to do genetic mapping of SCN5A gene. He denies previous illnesses and operations, his father died of a myocardial infarction at 47 years of age, mother and sister did not have any significant illnesses.

After two months of pacemaker implantation patient underwent complete cardiac examination. The repeated echocardiography, except the visible electrodes in the right heart chambers, showed that all parameters were within normal range. Repeated Holter monitoring (24h) showed that the patient was in sinus rhythm, maximal heart rate was $105 \mathrm{bpm}$, minimal $55 \mathrm{bpm}$, with no significant pauses. There was no ventricular premature beats, or malignant arrhythmias. The patient had no symptoms. At the same time patient's mother and sister, underwent through a complete cardiac examination, as well. ECG recording of both mother and sister showed right bundle branch block with no significant changes at the ST segment (Fig. 3). 
In 1992, Brugada syndrome was introduced as a new clinical entity linking typical but variable, ST segment changes in the right precordial leads to an increased vulnerability for lethal ventricular arrhythmias. In the affected patients, no structural heart disease could be identified despite through invasive and non-invasive investigation. Brugada syndrome is genetically transmissible disease manifesting as an autosomal dominant and age-dependent trait. Up till now, more than 80 causative gene mutations have been identified, mostly located on the SCN5A gene, encoding the pore-forming a subunit of the cardiac sodium channel. Large number of phenotypic variations within families and the overlap with other channelopathies illustrate the complex genetic heterogeneity underlying this syndrome [1]. The diagnosis of Brugada syndrome is based on clinical and electrocardiographic features. Patients present with syncope or (aborted) sudden cardiac death due to malignant ventricular arrhythmias. No apparent structural heart disease can be found. Three different ECG patterns all featuring ST segment elevations in the right

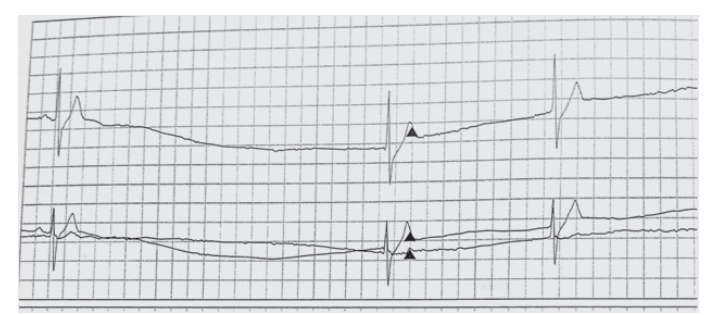

Figure 1. ECG recording from the initial 24-Holter Monitoring (24h) at the admission of our patient

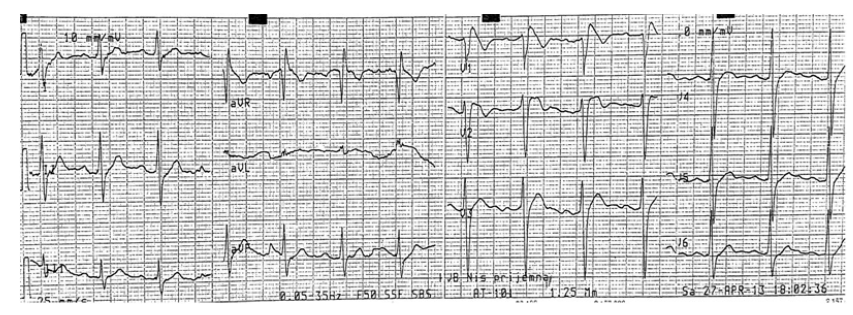

Figure 2. The patient's ECG recording.

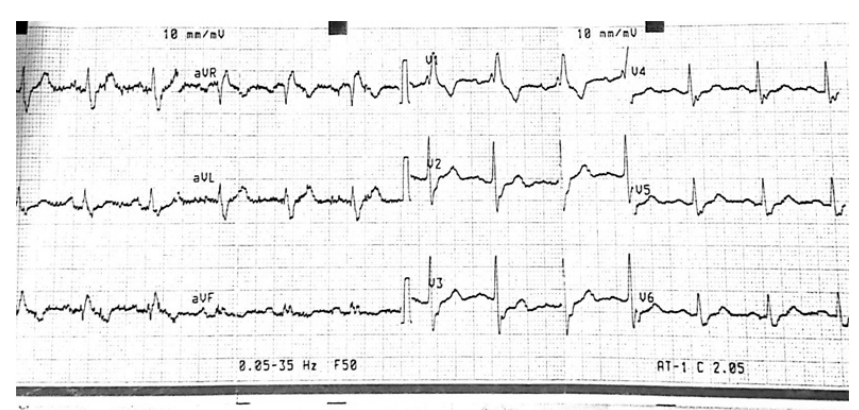

Figure 3. An ECG recording of the patient's sister. precordial leads have been recognized. Type I is the only pattern that is diagnostic for Brugada syndrome. It consist of a coved type ST segment elevation greater than $2 \mathrm{~mm}$, followed by a descending negative $\mathrm{T}$ wave in at least one right precordial lead: V1-V3. Type II and III are saddleback-shaped patterns, with a high initial augmentation followed by an ST elevation greater than $2 \mathrm{~mm}$ for type II and less than $2 \mathrm{~mm}$ for type III. Both patterns are suggestive of but not diagnostic for Brugada syndrome [2].

Multiple case reports of ECG patterns that mimic those of Brugada syndrome have been published. Possible causes of ST segment elevation in the right precordial leads are: anti-arrhythmic drugs (class IC and IA, calcium channel blockers as verapamil), acute ischemia in right ventricle outflow tract (RVOT), hyperthermia and hypothermia, elevated insulin level, etc.

Furthermore, recent studies illustrate the dynamic character of these ECG patterns. Whenever a large number of baselines ECG were available during follow up, the diagnostic pattern could be documented in only approximately $25 \%$ of the tracings.

Because the presence of the spontaneous coved type I ECG pattern is thought to be a useful predictor of future arrhythmic events in asymptomatic patients, these findings are of great clinical importance [3]. The class IC antiarrhythmic drug test provided a tool to unmask these concealed forms. Intravenous administration of ajmaline, flecainide or procainamide was able to elicit the diagnostic coved-type Brugada syndrome ECG pattern [4]. On the basis of the results of comparative studies and clinical experience, ajmaline, in a dose of $1 \mathrm{mg} / \mathrm{kg}$, is considered to be the preferred drug. Recently, the full stomach drug test was proposed as an alternative tool in diagnosing Brugada syndrome.

The episodes of syncope and sudden death are caused by fast polymorphic ventricular tachycardia or ventricular fibrillation. These arrhythmias appear with no warning. The first patient with Brugada syndrome was seen in 1986. The native populations of Asia knew about the problem for many decades. In the Philippines the problem was known as "bangungut", in Japan as "pokuri" (unexpected sudden death during sleep).

Currently more than 70 SCN5A mutations have been linked to Brugada syndrome, all creating an impaired sodium influx. The loss of function SCN5A mutations also have been described as being responsible for Lev-Lenegr disease, or progressive conduction defect. This phenotypic overlap is illustrated by the frequent occurrence of conduction abnormalities in patients with Brugada syndrome. Also SCN5A previously was shown to be the cause of LQT3 syndrome a form of Romano-Ward long QT syndrome. The differences in the clinical findings between LQT3 and Brugada are due to the different biophysical features dictated by the position of the mutations within the gene [5].

In the past decade, risk stratification in Brugada syndrome has become the subject of intense interest owing to 
the fact that early recognition of patients at increased future risk of sudden death can save many lives. The principal goal of risk stratification is the prediction of future arrhythmic events at any time during life. This is particularly difficult in adult patients who have never had any symptoms and in whom the diagnosis is incidental [6].

Asymptomatic persons may be recognized when the atypical ECG pattern is detected during routine examination. This ECG pattern cannot be distinguished from that in symptomatic patients. In other patients, the characteristic ECG pattern is recorded during screening after the sudden death of a family member with the disease. On the other hand, another group of symptomatic patients have been diagnosed as suffering syncope episodes of unknown cause or vasovagal origin or who have a diagnosis of idiopathic ventricular fibrillation. Subsequently, some of these patients are correctly diagnosed at follow up when ECG pattern changes spontaneously from normal to the typical pattern of the syndrome. This is also the case for those persons in whom the disease is unmasked by the administration of an antiarrhythmic drug given for other arrhythmias- for instance, atrial fibrillation [7].

\section{References}

1. Brugada P, Brugada J. Right bundle branch block, persistent ST segment elevation and sudden cardiac death: A distinct clinical and electrocardiographic syndrome. A multicenter report. J Am Coll Cardiol 1992; 20:1391-6.

2. Antzelevitch C, Brugada P, Borggrefe M et al. Brugada syndrome: Report of the Second Consensus Conference. Circulation 2005;111: 659-70.

3. Richter S, Sarkozy A, Chierchia GB, et al. Variability of the diagnostic coved type ECG during long term follow up of patients with Brugada syndrome and primary prophylactic ICD implantation. Eur Heart J 2008; 27 (S1).

4. Hong K, Brugada J, Oliva A, et al. Value of electrocardiographic parameters and ajmaline test in diagnosis of Brugada syndrome caused by SCN5A mutations. Circulation 2004;110: 3023-7.

5. Probst V, Allouis M, Sacher F, et al. Progresive cardiac conduction defect is the prevailing
An ICD pacemaker implantation is a treatment option for the patients with Brugada syndrome and ventricular tachycardia or fibrillation. Extensive research is ongoing to find alternative pharmacological options for these patients, especially for patients in whom an ICD implantation is contraindicated for various reasons. Quinidine and dimethyl lithospermate B (an extract of Danshen) have been suggested as drugs that reduce the tendency for ventricular arrhythmias. Larger patient groups and longer follow up period are necessary to evaluate these products [7-9].

In everyday clinical practice, we encounter patients with Brugada syndrome, and conduction abnormalities requiring permanent pacemaker implantation. Brugada syndrome in our patient was diagnosed due to specific ECG recording and genetic analysis of the SCN5A gene. Implantable cardioverter defibrillator was not the treatment option in our patient because he had no malignant arrhythmias as well as ventricular premature beats during the long follow-up period. Upgrade option of adding an ICD to in two-chamber pacemaker is advisable in adequate indication, and our patient is scheduled for regular check-ups every three months for complete cardiac examination.

phenotype in cariers of a Brugada syndrome SCN5A mutation. J Cardiovasc Electrophysio 2006;17: 270-5.

6. Coronel R, Casini S, Koopmann T, et al. Right ventricular fibrosis and conduction delay in a patients with clinical signs og Brugada syndrome. Circulation 2005;112: 2769-77.

7. Boussy T, Brugada R, Brugada J, et al. The Brugada Syndrome, In: Zippes, Jalife. Cardiac Electrophysiology, fifth edition. Saunders Elselvier 2009.

8. Hermida JS, Denjoy I, Clerc J, et al. Hydroquinidine therapy in Brugada syndrome. J Am Coll Cardiol 2004; 43: 1853-60.

9. Fish JM, Welchons DR, Kim Y, et al. Dimethyl lithospermate B, an extract of Danshen suppresses arrhythmogenesis associated with Brugada syndrome. Circulation 2006;113: $1393-400$. 